\title{
Restricted variability of a 17 nucleotide stretch within the 5 '-noncoding region of poliovirus genome
}

\author{
T. PÖYRY, L. KINNUNEN AND T. HOVI \\ Enterovirus Laboratory, Department of Virology, and Molecular Biology Lnit, \\ Virology Group, National Public Health Institute, Helsinki, Finland
}

(Accepted 31 May 1989)

\section{SLILMARY}

The outbreak of poliomyelitis in Finland in 1984 was caused by a wild strain of poliovirus 3 with uncommon molecular and antigenic properties. We prepared a synthetic oligonucleotide probe complementary to nucleotides $494-510$ in the 5 noncoding part of the genome of a representative strain of the outbreak. This short nucleotide stretch was found to be relatively well conserved within the outbreak and uncommon among 82 independent poliovirus isolates. It may thus be a useful marker for screening isolates to identify those requiring more detailed genetic comparison. The sequences of the corresponding region of the genome are known for 32 separate poliovirus strains and 3 coxsackie $B$ virus strains and show 6 fully conserved nucleotides that could assume a constant hairpin-loop position in a hypothetical secondary structure of the RNA. This could explain the persistence of a particular 17 nucleotide sequence for 40 years in nature in this highly rariable region of the poliovirus genome.

\section{INTRODLCTION}

An outbreak of poliomyelitis due to a wild type 3 strain of poliovirus occurred in Finland in 1984-5 (1). This was unexpected because the country had been free from the disease for 20 years and no signs of poliovirus circulation in the population had been obtained in thorough studies (2). The antigenic properties of the virus strains isolated during the outbreak have been shown to differ considerably from those of the type 3 strains (Sabin 3 and Saukett) that are used in poliovirus vaccines (3-5). Sequencing of the total genomic RNA of one of the isolates revealed several interesting differences from the 'reference' type 3 strain (P3/Leon) (6). These included a region in the 5 '-noncoding part of the genome with a nucleotide sequence identical to that of type 1 / Mahoney strain of poliovirus and spanning $16(7)$ or 17 (8) nucleotides. Only 8 of the 17 nucleotides show identical positions with those of the type 3 Leon strain (9).

We wanted to study whether this unexpected intertypic relationship is shared by the other strains isolated during the outbreak and whether this property could be used as a marker in the search for the origin of the outbreak. In this paper we describe initial studies based on screening poliovirus isolates for RNA sequence 
relationships and present a hypothesis for the persistence of a particular sequence in this highly variable region of the poliovirus genome.

\section{MATERIALS AND METHODS}

Virus strains

Eighty-eight out of 161 virus strains used in this study were isolated from the patients with poliomyelitis or healthy contacts of the patients, or their contacts. during the outbreak in Finland in 1984. Additional wild type strains of poliovirus 1,2 and 3 originally obtained from different parts of the world are listed in Table 1.

All strains were serotyped by neutralization with type-specific hyperimmune animal sera using either a stock virus preparation or after plaque purification (see Results). Some strains were examined for Sabin strain-specific antigenic properties using microneutralization as described by Huovilainen and colleagues (3).

Strains designated P3/Saukett were kindly provided by Dr P. D. Minor, National Institute for Biological Standards and Control, London. The other laboratory strains tested were originally obtained from the Regional Enterovirus Reference Laboratory. State Serum Institute, Copenhagen, and had been maintained for varying periods with various passage histories in the Enterovirus Laboratory, National Public Health Institute, Helsinki.

\section{Preparation of specimens for hybridization}

Monolayer cultures of Vero cells were infected at low multiplicity. The infected cell cultures were harvested when the cytopathic effect involved $80-100 \%$ of the cells. The cellular membranes were lysed with the nonionic detergent Nonidet P-

$\begin{array}{lll}\text { Table 1. Poliovirus strains used in the study } \\ \text { Strain } & \text { Year } & \text { Country of origin } \\ \text { P1/125/1/1 } & 1971 & \text { Czechoslovakia } \\ \text { P1/157/1/10 } & 1971 & \text { CSA } \\ \text { P1/178/2/7 } & 1972 & \text { Poland } \\ \text { P1/Atlanta 1-1 } & 1957 & \text { CSA Arkansas } \\ \text { P1/Atlanta 77675 } & 1955 & \text { CSA Hawaii } \\ \text { P1/Atlanta 04958 } & 1977 & \text { Kuwait } \\ \text { P1/Atlanta } 13021 & \text { NK } & \text { Brazil } \\ \text { P1/Atlanta 5/78 } & 1978 & \text { Ioroceo } \\ \text { P1/Atlanta } 7 / 79 & 1979 & \text { Iorocco } \\ \text { P1/98/82 } & 1982 & \text { Italy } \\ \text { P1/12127 } & 1976 & \text { Greece } \\ \text { P1/NE-459/82 } & 1982 & \text { Spain } \\ \text { P1/Braz/8-3827/81 } & 1981 & \text { Brazil } \\ \text { P1/Rom/53903/81 } & 1981 & \text { Romania } \\ \text { P1/HK/15/81 } & 1981 & \text { Hong Kong } \\ \text { P1/11FJ } & \text { NK } & \text { Sweden/India } \\ \text { P1/1400 } & 1980 & \text { Nexico } \\ \text { P1/4969 } & 1983 & \text { Saudi Arabia } \\ \text { P1/18389 } & 1976 & \text { CK } \\ \text { P1/2069/77 } & 1977 & \text { CK } \\ \text { P1/2 } & \text { NK } & \text { Finland }\end{array}$


Table 1. (cont.)

\begin{tabular}{|c|c|c|}
\hline Strain & Year & Country of origin \\
\hline $\mathrm{P} 1 / 3-3855 / 62$ & 1962 & Finland \\
\hline $\mathrm{P} 1 / 4-\mathrm{X} 1 / 56$ & 1956 & Finland \\
\hline $\mathrm{P} 1 / 5-4032 / 62$ & 1962 & Finland \\
\hline $\mathrm{P} 1 / 7-\mathrm{TF} / 60$ & 1960 & Finland \\
\hline $\mathrm{P} 1 / 9-\mathrm{TJ} / 59$ & 1959 & Finland \\
\hline $\mathrm{P} 1 / 11 / 59$ & 1959 & Finland \\
\hline $\mathrm{P} 1 / 12-1113 \mathrm{~L} / 60$ & 1960 & Finland \\
\hline $\mathrm{P} 1 / 13-3848 / 62$ & 1962 & Finland \\
\hline $\mathrm{P} 1 / 14 / 59$ & 1959 & Finland \\
\hline $\mathrm{P} 2 / 172 / 2 / 7$ & 1972 & Poland \\
\hline $\mathrm{P} 2 / 185 / 2 / 3$ & 1973 & UK \\
\hline $\mathrm{P} 2 / \mathrm{II}-215$ & 1959 & Venezuela \\
\hline \multirow[t]{2}{*}{ P2/II-299 } & 1952 & USA \\
\hline & & California \\
\hline P2/II-316 & 1952 & Egypt \\
\hline $\mathrm{P} 2 / \mathrm{II}-364$ & 1956 & India Bombay \\
\hline P2/Lennette 77726 & 1954 & USA California \\
\hline $\mathrm{P} 2 / 76 / 78$ & 1978 & Morocco \\
\hline $\mathrm{P} 2 / 92 / 78$ & 1978 & Morocco \\
\hline $\mathrm{P} 2 / 4141 / 82$ & 1982 & UK \\
\hline $\mathrm{P} 2 / \mathrm{II}-867$ & 1974 & USA Maryland \\
\hline $\mathrm{P} 2 / 273 / 82$ & 1982 & Spain \\
\hline $\mathrm{P} 2 / 81-4789$ & 1981 & Korea \\
\hline $\mathrm{P} 2 / \mathrm{B} 1139$ & 1982 & Kuwait \\
\hline P2/LS 2575 & 1980 & Kuwait \\
\hline $\mathrm{P} 2 / 5394$ & 1983 & Saudi Arabia \\
\hline $\mathrm{P} 2 /$ Eng $/ 23 / 84$ & 1984 & England \\
\hline $\mathrm{P} 2 / 282 / \mathrm{N} / 84$ & 1984 & Spain \\
\hline $\mathrm{P} 2 / 121 / 84$ & 1984 & Spain \\
\hline $\mathrm{P} 2 / 967 / \mathrm{N} / 84$ & 1984 & Spain \\
\hline $\mathrm{P} 3 / 177 / 2 / 7$ & 1972 & Poland \\
\hline P3/III-1 & 1957 & USA New Mexico \\
\hline P3/III-2 & 1958 & USA Indiana \\
\hline $\mathrm{P} 3 / \mathrm{III}-5$ & 1958 & CSA Washington DC \\
\hline P3/III-10 & 1957 & LSA Georgia \\
\hline P3/III-374 & 1957 & Japan \\
\hline P3/III-715 & 1958 & India Bombay \\
\hline P3/Lennette 77750 & 1953 & USA California \\
\hline $\mathrm{P} 3 / 137 / 1976$ & 1976 & Hungary \\
\hline P3/109/76 & 1976 & Morocco \\
\hline $\mathrm{P} 3 / 40 / 82$ & 1982 & Spain \\
\hline P3/Ext 2672 & 1980 & France \\
\hline $\mathrm{P} 3 / 82-18714$ & 1982 & Turkey \\
\hline $\mathrm{P} 3 / 1838 / 83$ & 1983 & Spain \\
\hline $\mathrm{P} 3 / 1293 / 83$ & 1983 & Spain \\
\hline P3/1573/83 & 1983 & Spain \\
\hline P3/E684 & 1957 & Sweden \\
\hline $\mathrm{P} 3 / 476 / 62$ & 1962 & L'K \\
\hline $\mathrm{P} 3 / 6 / 62$ & 1962 & LK \\
\hline
\end{tabular}




\section{TuiJa Pöyry, Leena Kinnunen and Tapani Hovi}

40 as $0.5 \%$ in phosphate buffered saline and the lysates were kept on ice for 10 $\mathrm{min}$. They were then gently vortexed and the nuclei were pelleted at $1000 \mathrm{~g}$ for 10 min. The supernatant was removed and treated with proteinase $\mathrm{K}$ (Merck $\mathrm{AG}$. Darmstadt, Federal Republic of Germany) at a concentration of $0 \cdot 1 \mathrm{mg} / \mathrm{ml}$ for $2 \mathrm{~h}$ at $37^{\circ} \mathrm{C}$. The $\mathrm{RNA}$ in the specimens was usually probed without further purification. For certain purposes (see Results) the proteinase $\mathbf{K}$-treated preparations were extracted with an equal volume of phenol-chloroform-isoamyl alcohol $(25: 24: 1)$ and used as such or after precipitation of the RNA with ethanol. The RNA in the specimens was denatured by adding formaldehyde to a final concentration of $6.5 \%(\mathrm{v} / \mathrm{v})$ and incubating for $15 \mathrm{~min}$ at $65^{\circ} \mathrm{C}$. Then $20 \times \mathrm{SSC}$ $(1 \times \mathrm{SSC}=0.15$ i $\mathrm{NaCl} .0 .015$ u sodium citrate. $\mathrm{pH} 7.0)$ was added to make a final concentration of $6 \times \mathrm{SSC}$. Samples representing $10^{6}$ cells were spotted onto nitrocellulose filters (BA 85. Schleicher \& Schuell Co.. Dassel, Federal Republic of Germany) with a micro-sample filtration manifold (Minifold II. Schleicher \& Schuell Co.). After air-drying the filters were baked at $80^{\circ} \mathrm{C}$ for $2 \mathrm{~h}$.

\section{Labelling of oligonucleotide}

The synthetic oligonucleotide $\left(5^{\prime}\right.$-AATCACTGGTTTGTGA('-3') was purchased from the Department of Medical Chemistry. University of Helsinki and labelled according to the manufacturers instructions at the $5^{\prime}$ end with ${ }^{32} \mathrm{P}$ using bacteriophage $\mathbf{T} 4$ polynucleotide kinase (Boehringer. Mannheim. Federal Republic of Germany). The reaction mixture $(50 \mu \mathrm{l})$ contained 10 pmol of the probe. $0.1 \mathrm{M}$ Tris-HCl (pH 7.6), $20 \mathrm{~mm} \mathrm{IgCl}_{2}, 0 \cdot 2 \mathrm{~mm}$ EDTA, $50 \mathrm{mu}$ dithiotreitol. $10 \mathrm{C}^{\mathrm{T}}$ of kinase, $50-75 \mu \mathrm{Ci}\left(\gamma_{-}{ }^{32} \mathrm{P}\right) \mathrm{ATP}(>5000 \mathrm{Ci} / \mathrm{mmol}$. Amersham International Plc. England). Sterile distilled water was added as necessary to make the final rolume $50 \mu \mathrm{l}$. After $1 \mathrm{~h}$ incubation at $37^{\circ} \mathrm{C}$ the kinase was denatured by heating for 10 $\min$ at $65^{\circ} \mathrm{C}$.

Labelled oligonucleotide was separated from free $\left(\gamma^{32} \mathrm{P}\right) \mathrm{ATP}$ by chromatography on Sephadex G-25 and used directly in hybridization. The specific activities of the probe were in the range $39 \times 10^{8} \mathrm{cpm} / \mu \mathrm{g}$.

\section{Hybridization assay}

The filters were hybridized in a plastic bag with the ${ }^{32} \mathrm{P}$-labelled probe $\left(10^{6}\right.$ $\mathrm{cpm} / \mathrm{ml})$ in $5 \times \mathrm{SSC}, 5 \times$ Denhardt s solution. $0.1 \%$ sodium dodec $r$ sulphate (SDS) for 4 to $16 \mathrm{hr}$ at $T_{\mathrm{m}}-8{ }^{\circ} \mathrm{C}$. $T_{\mathrm{m}}$ in ${ }^{\circ} \mathrm{C}$ was estimated by the formula $T_{\mathrm{m}}=$ $(\mathrm{A}+\mathrm{T}) 2+(\mathrm{G}+\mathrm{C}) 4$. After hybridization the filters were washed three times for $5 \mathrm{~min}$ in $5 \times \mathrm{SSC}, 0.5 \% \mathrm{SDS}$ at $T_{\mathrm{m}}$. Washed filters were exposed to Kodak $X$-Omat AR film with two intensifier screens for $16-48 \mathrm{~h}$.

\section{Tirus purification for RIA sequencing}

Viruses were grown in HEp-2 cells in the presence of ${ }^{35} \mathrm{~S}$-methionine and the cells were collected when a cytopathic effect was observed in $80-100 \%$. The cells were lysed with nonionic detergent Nonidet $\mathrm{P}-40(0.5 \%$ in PBSi) and kept on ice for $10 \mathrm{~min}$. The cell homogenate was slightly vortexed and cleared of cell debris by centrifugation for $10 \mathrm{~min}$ at $1000 \mathrm{~g}$ at $4^{\circ} \mathrm{C}$. Sodium dodecyl sulphate (SDS) was added to the supernatant to a final concentration of $0.5 \%$. The virus was pelleted from the supernatant by layering it over a $2 \mathrm{ml} 20 \%$ sucrose cushion and 
centrifuging at $38000 \mathrm{rpm}$ for $2 \mathrm{~h}$ at $15^{\circ} \mathrm{C}$ in an $\$ 1 W^{4} 40$ rotor (Beckman Instruments. Inc.). The virus was further purified by velocity sedimentation in a $15 \%-30 \%$ sucrose gradient at $38000 \mathrm{rpm}$ for $1.5 \mathrm{~h}$ in an $\mathrm{SW} 40$ rotor and pelleted from the peak radioactive fractions.

\section{Extraction of ririon RNA}

Purified virus was diluted in $0 \cdot 15$ y sodium acetate and $0 \cdot 1 \%$ SDS. The mixture was extracted sequentially with phenol-chloroform-isoamyl alcohol $(25: 24: 1)$, phenol. chloroform and ether. The RNA was then ethanol-precipitated, dried and dissolved in water at a concentration of approximately $1 \mu \mathrm{g} / \mu \mathrm{l} .5 \mathrm{U}$ of RNase inhibitor (Boehringer. Mannheim) per $\mu \mathrm{g}$ was added.

\section{Primer extension sequencing}

The viral RNA was sequenced directly by the dideoxynucleotide chain termination method of Sanger and his coworkers (10). The primer used had the sequence $5^{\prime}$ GTAGTCGGTCCGCC $3^{\prime}$ and was synthesized at the Department of Iedical ('hemistry. Lniversity of Helsinki. The hybridization mixture contained approximately $1 \mu \mathrm{g}$ of template and $20 \mathrm{ng}$ of primer. The mixture was heated at $90^{\circ} \mathrm{C}$ ' for $1 \mathrm{~min}$ and allowed to cool to room temperature. Then $2 \cdot \tilde{\mathrm{s}} \mu \mathrm{l}$ of water and $0.5 \mu \mathrm{l}$ of reverse transcription buffer (final concentration : $50 \mathrm{~mm}$ Tris- $\mathrm{HCl} \mathrm{pH} 8 \cdot 3$, $6 \mathrm{~m} v \mathrm{lg}\left(\mathrm{l}_{2}, 40 \mathrm{mu} \mathrm{KCl}\right)$ were added. One $\mu \mathrm{l}$ of this mixture was added to each of four tubes containing $1 \mu \mathrm{l}$ of deoxynucleotide/dideoxynucleotide mixture, $8 \mu \mathrm{Ci}$ of ${ }^{35} \mathrm{~S}$-labelled $\operatorname{dATP}(>1000 \mathrm{Ci} / \mathrm{mmol}$, Amersham Corp., London, England) and $5 \mathrm{C}$ of reverse transcriptase ( $P \& \&$ Biochemicals Limited, Liverpool, England) in a final volume of $3 \mu \mathrm{l}$. The A reaction contained $555 \mu \mathrm{M}$ each dCTP, dGTP, dTTP and $1.4 \mu \mathrm{M}$ dideoxy ATP. The C reaction contained $55.5 \mu \mathrm{u}$ each dGTP and dTTP. $11 \cdot 1 \mu \mathrm{M}$ d( $\mathrm{TP}$ and $2 \cdot 8 \mu \mathrm{M}$ dideoxy CTP. The G reaction contained $55.5 \mu \mathrm{M}$ each d('TP and d'TTP, $11 \cdot 1 \mu \mathrm{M} \mathrm{dGTP}$ and $2 \cdot 8 \mu \mathrm{M}$ dideoxy GTP. The T reaction contained $55.5 \mu \mathrm{x}$ each dCTP and dGTP, $11 \cdot 1 \mu \mathrm{M}$ dTTP and $2 \cdot 8 \mu \mathrm{x}$ dideoxy TTP. Each reaction mixture was incubated at $42{ }^{\circ} \mathrm{C}$ for $30 \mathrm{~min}$ and then a chase mix containing $250 \mu$ s each dATP, dC'TP, dGTP and dTTP in $100 \mathrm{mu}$ Tris-HCl pH 8.3. was added and incubation continued for $15 \mathrm{~min}$. The reaction was stopped by adding $5 \mu \mathrm{l}$ of formamide-dye mix. The specimens were heated for $2 \mathrm{~min}$ at $90^{\circ} \mathrm{C}$ before loading onto $6 \%$ polyacrylamide buffer gradient gel (11). After electrophoresis the gel was soaked for $10 \mathrm{~min}$ in $10 \%$ acetic acid, $10 \%$ methanol and dried at $80^{\circ} \mathrm{C}$ under vacuum before autoradiography (Hyper film $\beta$ max, Amersham ('orp., England) for $12-48 \mathrm{~h}$.

\section{RESLITS}

\section{Sensitirity and sperificity of oligonucleotide hybridization}

To evaluate the sensitivity and specificity of the test, serial dilutions of the RNA prepared from P1/Mahoney, P3/Leon or P3/Sabin infected or uninfected Vero cells were probed with the labelled oligonucleotide complementary to the sequence on P1/Mahoney strain. The probe regularly detected RNA from $10^{4}$ homologously infected cells and showed no cross-reactions with preparations derived from the Leon or Sabin 3 infected or uninfected Vero cells (Fig. 1). 
(a)

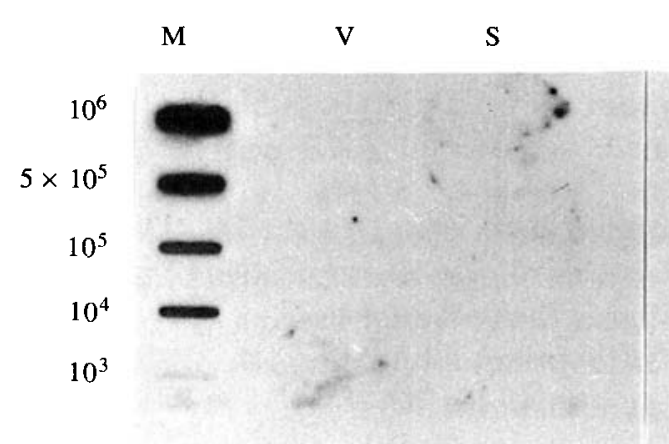

(b)

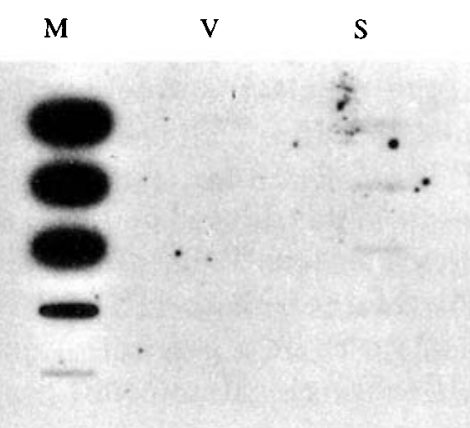

Fig. 1. Sensitivity of the oligonucleotide hybridization reaction. Proteinase $\mathrm{K}$ - treated (a) cytoplasmic extracts of Vero cells infected with P1/Mahoney (M), P3/Sabin (S) or uninfected Vero cells (V) were spotted on nitrocellulose filters and tested with the P1/Mahoney probe. The corresponding cell numbers are shown on the left. In panel $b$ the proteinase $\mathrm{K}$-treated extracts were deproteinized with the phenol-mixture and probed as in panel $a$.

\section{Homology within an outbreak}

To test the stability of the RNA sequence in this region within an outbreak, poliovirus type $3 /$ Finland/84 strains isolated from 88 persons were grown in Vero cells and the proteinase $\mathrm{K}$-treated cytoplasmic extracts were probed with the oligonucleotide. All virus strains were recognized by the Mahoney probe. Six strains showed relatively weak, fuzzy and variable signals in the screening test (for instance C15 in Fig. 2). Ethanol-precipitated RNA preparations were, however, undoubtedly positive for the Mahoney probe (data not shown).

\section{Variation among independent poliovirus isolates}

To test the variation of this region among poliovirus strains in general we first assayed 12 laboratory strains. Apart from the expected reactions only one strain. P1/Charleston, could be detected with the Mahoney probe. It is noteworthy that P2/Sabin, which differs from the Mahoney strain by only three nucleotides (Table 4 ), showed no signal with the Mahoney probe (Table 2).

Ten wild type 1 strains isolated in Finland in the 1950s were negative with the probe. Sixty strains, 20 of each serotype, from the collections of National Institute for Biological Standards and Control, London, UK, isolated in various regions in the world between 1952 and 1984 were also tested. Six strains were positive with the Mahoney probe and these included representatives from all serotypes ('Table 3 ). Three out of four probe positive type 1 poliovirus isolates showed Sabin-like antigenic properties in the microneutralization test.

The latter 60 strains were tested both before and after phenol extraction. As with the P3/Finland/84 strains, the specimens showing a weak, fuzzy signal when tested as a crude preparation, were clearly positive when tested after phenol extraction (Fig. 3). Use of phenol-extracted RNA did not increase the number of strains scored as positive. 


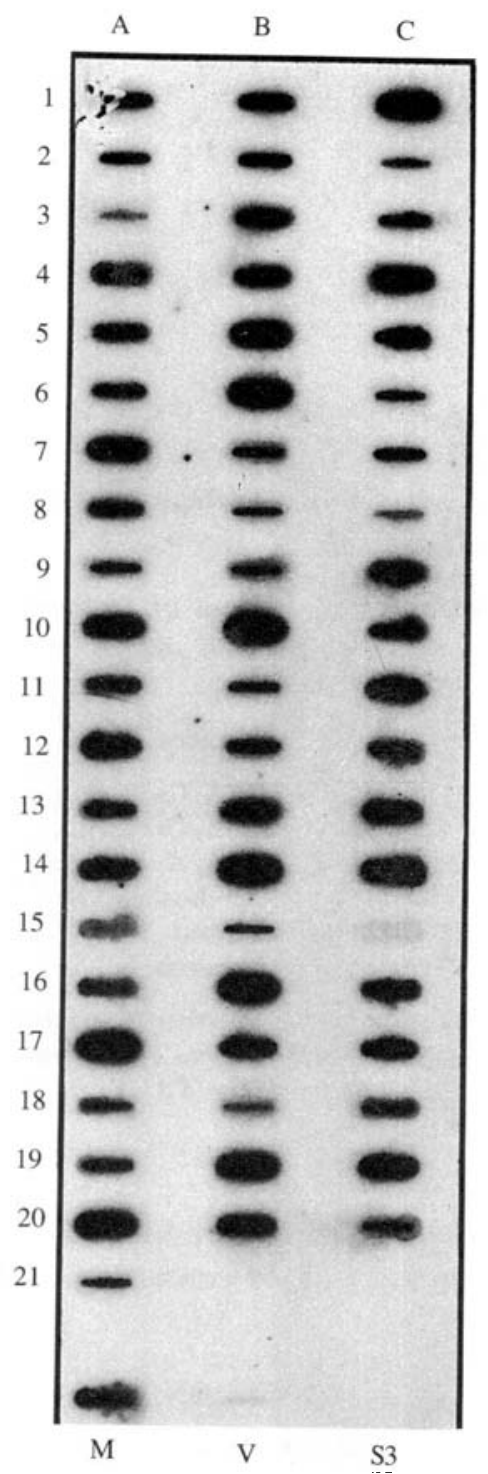

Fig. 2. Homogeneity of type 3 poliovirus strains isolated in Finland in 1984. Proteinase K-treated cytoplasmic extracts of about $10^{6}$ Vero cells infected with 61 different strains of type 3 poliovirus isolated in Finland in 1984 were spotted on nitrocellulose filters and tested with the Mahoney probe (columns A, B and C). M, P1/Mahoney; $V$. uninferted Vero cells; S3. P3/Sabin.

Lariation of nucleotide sequence in the probed region of RNA

Genomic RNAs from five strains showing a positive signal with the Mahoney probe and 10 non-reacting strains were sequenced using the primer extension method. Results in Table 4 indicate that, among this limited member of isolates, mismatches greater than one nucleotide were not accepted by the hybridization test. Another aspect evident from Table 4 is that the 17 nucleotide stretch probed 
Table 2. Hybridization results of 'laboratory strains' with the Mahoney probe

$\begin{array}{lc}\text { Virus strain } & \text { Results } \\ \text { P1/Brunhilde } & - \\ \text { P1/Charleston } & + \\ \text { P1/Mahoney } & + \\ \text { P1/Sabin } & + \\ \text { P2/MEF-1 } & - \\ \text { P2/Sabin } & - \\ \text { P3/Leon } & - \\ \text { P3/Sabin } & - \\ \text { P3/Saukett* } & -\end{array}$

* Seven strains maintained at different laboratories were tested separately.

Table 3. Positive hybridization reactions out of 70 unrelated poliovirus isolates tested (Mahoney probe)

\begin{tabular}{|c|c|c|c|}
\hline Virus strain & Year & Country & $\begin{array}{l}\text { Location in } \\
\text { Fig. } 3\end{array}$ \\
\hline $\mathrm{P} 2 / \mathrm{II}-299$ & 1952 & USA/California & B4.E4 \\
\hline P3/Lennette 77750 & 1953 & USA/California & $(8, F 8$ \\
\hline P1/Atlanta 1-1 & 1957 & USA/Arkansas & At.D4 \\
\hline $\mathrm{P} 1 / 125 / 1 / 1^{*} \dagger$ & 1971 & Czechoslovakia & A1.D1 \\
\hline $\mathrm{P} 1 / 178 / 2 / 7 \dagger$ & 1972 & Poland & A3.D3 \\
\hline $\mathrm{P} 1 / 76 / 78 t_{+}^{+}$ & 1978 & Moroceo & B8. I) 22 \\
\hline
\end{tabular}

* Strains were isolated from patients who had recently received OPY.

$\dagger$ These strains showed Sabin 1-like immunological characteristics.

$\ddagger$ This is a plaque purification derivative of the $\mathrm{P} 2 / 76 / 78$ strain that turned out to be a mixture of type 1 and type 2 polioviruses.

in the above experiments is indeed highly variable between independent poliovirus isolates. However, it contains a set of six conserved nucleotides ('-A-C $\mathrm{AC}$.

\section{DISCLSSION}

We have used an oligonucleotide hybridization test for initial screening of RNA sequence relationships between poliovirus isolates. Our results reported in this paper show that a 17 nucleotide sequence in the $5^{\prime}$-noncoding region that is identical in type 1/Mahoney and type 3/Finland/23127/84 strains, is also possessed by all 88 other type $3 /$ Finland/84 strains tested but is relatively rare among other unrelated type 3 poliovirus isolates. The probe thus seems to be suitable for searching for possible genetic relatives of the P3/Finland strain. The method is relatively easy to use for large numbers of specimens since proteinase $\mathrm{K}$ treated cytoplasmic extracts gave practically identical results with phenolextracted specimens.

Oligonucleotide hybridization is a sensitive test capable of detecting one nucleotide mismatch provided that the stringency of the assay conditions is high enough $(13,14)$. Since we wanted to develop an assay for detecting relatedness between virus isolates, a mismatch of one or two nucleotides would still be 
A

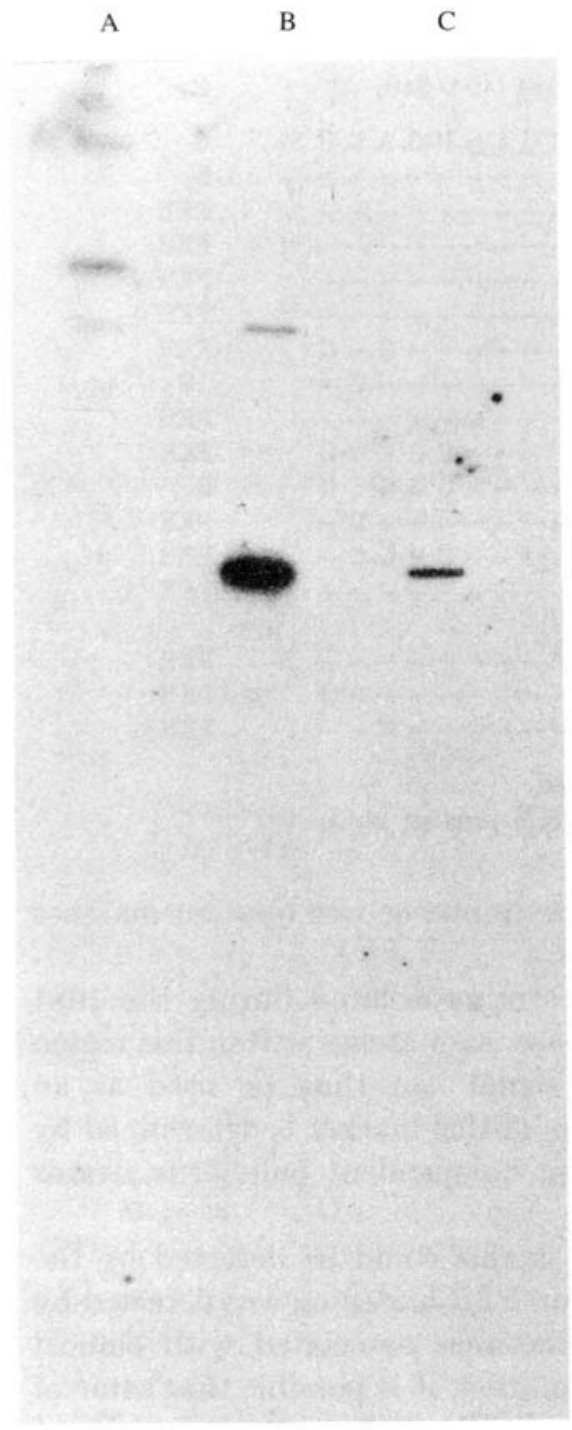

D

$\mathrm{E}$

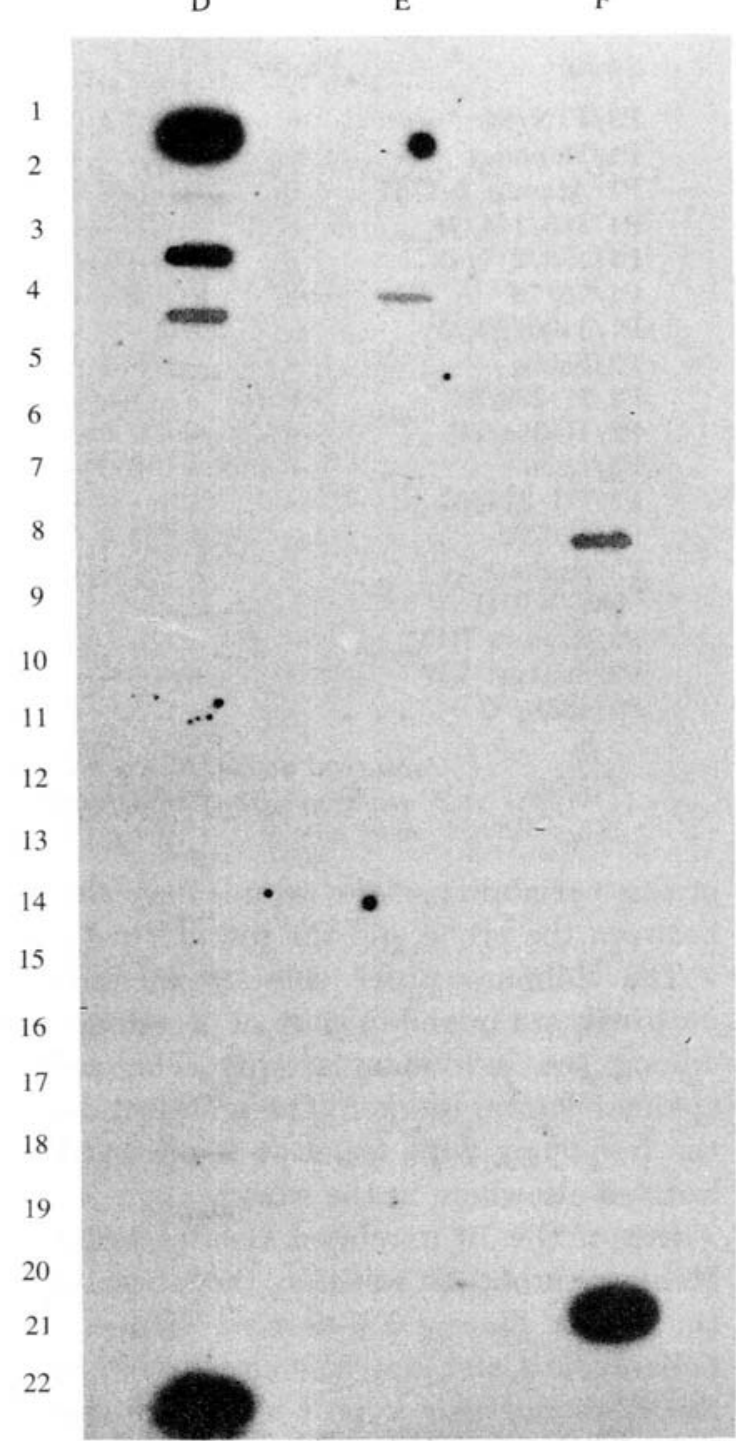

Fig. 3. I istribution of $\mathrm{Pl} /$ Mahoney-related sequences among 60 unrelated poliovirus isolates (see Table 1). For details see legend for Fig. 2. Columns A to F. reactions with the Vlahoney probe. ('olumns I) to F show confirmatory experiments with phenolextracted specimens and the Mahoney probe. The specimens are as in $A$ to $\mathrm{C}$ except that B8 was translocated to D22 and P1/Mahoney control was added to location F21.

acceptable. Sequencing the genomic RNA of selected strains in this region suggested that this indeed was the case. Of course, the location of the mismatch may influence the results but a greater number of sequences would be required to evaluate this. The intensity of the positive signal varied from strain to strain, although we attempted to use a standard amount of infected cells per specimen. The amount of RNA synthesized per cell may vary between virus strains but part 
Table 4. Known nucleotide sequences in the probed region of poliovirus RNA

\begin{tabular}{|c|c|c|c|}
\hline Strain & Probe* & Sequence $(494-510)$ & Ref. \\
\hline P3/FIN/84 & + & $5^{\prime} \mathrm{G} U \mathrm{CA} \underline{\mathrm{C}} \mathrm{A} \underline{\mathrm{A}} \mathrm{A} \underline{\mathrm{C}} \mathrm{CA} \mathrm{A} U \mathrm{UA} \mathrm{AU} 3^{\prime}$ & 6 \\
\hline P1/Mahoney & + & $------------\cdots$ & 8 \\
\hline P1/Atlanta 1-1/57 & + & $-----G----------$ & PKH \\
\hline $\mathrm{P} 1 / 125 / 1 / 1 / 71$ & + & $-------\mathrm{G}--------$ & SKH \\
\hline $\mathrm{P} 1 / 178 / 2 / 7 / 72$ & + & ---------------- & $\mathrm{KH}$ \\
\hline $\mathrm{P} 1 / 76 / 78$ & t & $------------\cdots$ & $\mathrm{PKH}$ \\
\hline P1/1400/80 & - & A $C-----G------G-C$ & $\mathrm{KH}$ \\
\hline P2/Sabin & - & $---\mathrm{G}-\mathrm{G}--------\mathrm{C}-$ & 12 \\
\hline $\mathrm{P} 2 / \mathrm{II}-299 / 52$ & + & $-----G---------$ & $\mathrm{PKH}$ \\
\hline $\mathrm{P} 2 / \mathrm{II}-364 / 56$ & - & $--\mathrm{U} G---\mathrm{C}----\mathrm{CA}-\mathrm{C} \mathrm{C}$ & $\mathrm{KH}$ \\
\hline P3/Leon & - & $-\mathrm{C} U \mathrm{G}---\mathrm{C}---\mathrm{CA} \mathrm{A} \mathrm{C} \mathrm{C}$ & 9 \\
\hline P3/III-374/57 & - & $\mathrm{A}-----\mathrm{G}-------\mathrm{C}-$ & PKH \\
\hline P3/476/62 & - & A C U G $-------C$ A G C - & PKH \\
\hline $\begin{array}{l}\text { P3/Saukett } \\
\text { BW/NPHI }\end{array}$ & $\cdots$ & $\mathrm{A}-----\mathrm{G}-------$ & $\mathrm{PKH}$ \\
\hline P3/Saukett RIT & - & $\mathrm{A}-----\mathrm{G}--------$ & $\mathrm{PKH}$ \\
\hline P3/Saukett VW & - & $\mathrm{A}------\mathrm{U}-------\mathrm{G}$ & PKH \\
\hline P3/1838/83 & - & $-\mathrm{C}----------\mathrm{G}--$ & $\mathrm{PKH}$ \\
\hline
\end{tabular}

Conserved nucleotides are underlined.

* reaction with Mahoney probe; PKH present study.

of this variability of the signals may also be due to one or two base mismatches between the probe and the tested viral genome.

The Mahoney probe detected all tested 88 strains isolated during the 1984 outbreak in Finland in spite of occasional one-base mismatches within this region among the individual strains. The positive signal can thus be used as an epidemiological marker. The practical usefulness of this marker is determined by the frequency with which it is observed among independent poliovirus strains isolated elsewhere in the world.

Out of the 70 unrelated isolates tested, six strains could be detected by the Mahoney probe. In addition, the laboratory strain P1/Charleston was detected by the probe. Since OPV-derived viruses are sometimes associated with elinical poliomyelitis and may also circulate in the population, it is possible that some of the 'Mahoney-like' type 1 isolates in this kind of strain collection may turn out to be OPV-derived descendants of Mahoney-Sabin 1. Indeed. three out of the four laboratory type 1 strains used in this study had Sabin 1-like antigenic properties. However, since the six Mahoney-probe positive strains also included representatives of all three serotypes isolated in USA in 1950s, we can conclude that this sequence, or a sequence very similar to it, is not confined completely to P1/Mahoney and P3/Finland/84 strains only. Whether the P3/Lennette/ $77750 / 53$ strain which shares homology in this sequence with P1/Mahoney is an ancestor of the P3/Finland/84 strains remains to be shown by more detailed comparisons. It will also be interesting to see if strains sharing this sequence with P1/Mahoney and P3/Finland/84 can be found among wild type isolates from $1960 \mathrm{~s}$ and $1970 \mathrm{~s}$.

While the results with the Mahoney probe were easy to score as either negative or positive we had technical difficulties with another probe complementary to the corresponding sequence of P3/Leon strain. The latter gave irregular results with 


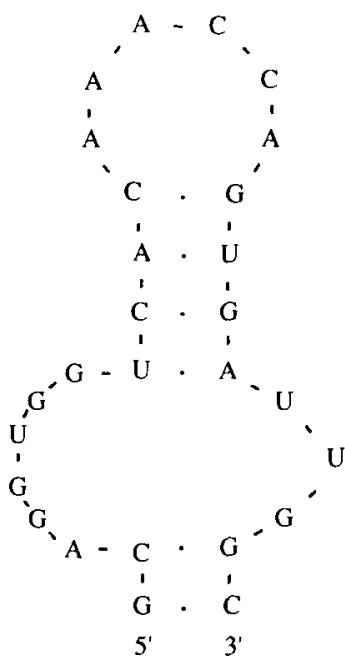

P1/Mahoney

$\Delta \mathrm{G}=-2 \cdot 6$

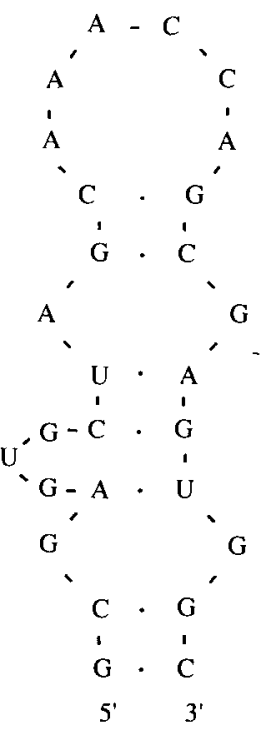

$\mathrm{P} 1 / \mathrm{HK} / 15 / 81$

$\Delta \mathrm{G}=-2 \cdot 2$

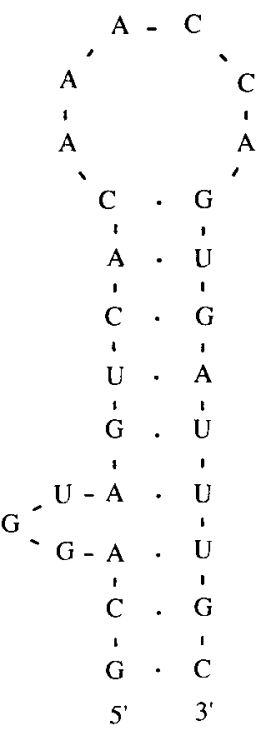

P3/Finland/84

$\Delta \mathrm{G}=-4.6$

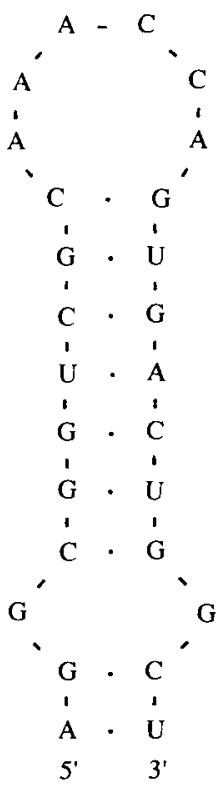

P2/Sabin

$\Delta \mathrm{G}=-6 \cdot 8$

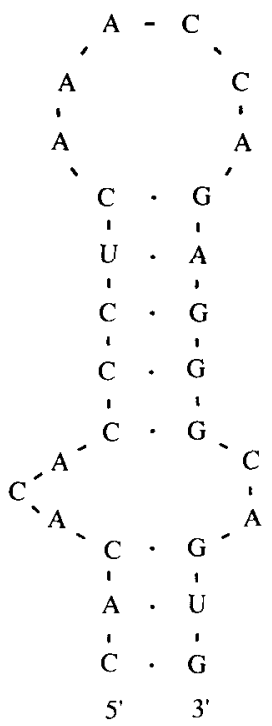

Cox B3

$\Delta \mathrm{G}=-11.6$

Fig. 4. Hypothetical base pairing close to the probed region in enterovirus genomes. The sequences are according to Racaniello and Baltimore (8, P1/Mahoney); Hughes et al. (6, P3/Finland/84); Toyoda et al. (12, P2/Sabin); Minor and Dunn (17, P1/HK/15/81); Stanway et al. (9, P3/Leon); Lindberg et al. (20, Cox B3). The calculated free energies for the suggested secondary structure are shown in the figure (23). 
both P3/Leon and P3/Sabin infected cells and reacted variably with uninferted cells (data not shown). Therefore, careful characterization of the reaction patterns of an oligonucleotide probe is necessary before it can be used in epidemiological studies.

There are two possible explanations for the existence of an identical sequence in the type 3/Finland/84 strains and the type 1/Mahoney strain isolated more than 40 years earlier. Firstly, a recombination between a wild type 3 strain and the type 1 Mahoney-derived attenuated Sabin 1 strain, which is widely used in oral polio vaccinations, cannot be ruled out. The other possibility is that certain sequence variations may be more favourable for the persistence of the strain than some others.

The exact RNA sequence of this region is known for 32 different strains of poliovirus (Table 4, Pöyry, Kinnunen and Hovi, unpublished: 15-17) and indicates wide variation without any serotype-dependence. Variability of the sequence does not necessarily mean lack of specific function since this region is known to be required for successful replication of poliovirus in ritro (18). Furthermore, a set of six nucleotides within this highly variable region was found to be fully conserved. Three serotypes of coxsackie $B$ viruses also share this six nucleotide set $(19,20,21)$. Computer-predicted secondary structure of the RNA of type 3 poliovirus of the Leon strain suggests that the region probed with our oligonucleotides is located close to the end loop of a 27 nucleotide hairpin structure involving nine base pairs (22). By taking into account possible base pairing close to this region alone it is possibly to construct an alternative model of the secondary structure which provides the conserved six nucleotides with a constant loop position in all 32 cases (Fig. 4). While this manuscript was in preparation. Rivera and coworkers published another computer model of the secondary structure of the $5^{\prime}$ noncoding region of genomic RNA suggesting a well-conserved pattern among various picornaviruses. The loop deduced from the sequences in the present study also exists in the computer model (24).

In conclusion, we have shown in this paper that a 17 nucleotide sequence shared by the P1/Mahoney and P3/Finland strains, is rare among independent type 3 poliovirus isolates while being relatively stable within the outbreak in Finland. A probe recognizing this region of RNA has therefore been used as one tool in further searchers for the origin of the outbreak. Since some strains of the two other serotypes were also recognized by this probe, other methods, such as partial RNA sequencing of selected regions of the genome, is being used in these st udies as well.

\section{ACKNOWLEDGENEXTS}

We are grateful to Dr David Magrath for the 60 clinical poliovirus isolates and to Ms Päivi Hirttiö for expert technical assistance. This work was supported by grants from the Finnish Academy and the Sigrid Juselius Foundation. Helsinki. Finland.

\section{REFERENCES}

1. Hovi T. Cantell K. Huovilainen A. et al. Outbreak of paralytic poliomyelitis in Finland: widespread circulation of antigenically altered poliovirus type 3 in a vacinated population. Lancet 1986 ; i : $1427-32$. 
2. Iapinleimu K. Elimination of poliomyelitis in Finland. Rer Infect Dis 1984: 6 (Suppl. 2): 45760 .

3. Huovilainen A. Hovi T.. Kinnunen L. Takkinen K. Ferguson M. Minor P. Evolution of poliovirus during an outbreak: Sequential type 3 poliovirus isolates from several persons show shifts of neutralization determinants. J Gen Virol 1987;68: 1373-8.

4. Huovilainen A. Kinnunen I. Ferguson M, Hovi T. Antigenic variation among 173 strains of type-3-poliovirus/Finland/84-85. J Gen Virol 1988; 69: 1941-8.

5. Magrath DI. Evans DMA. Ferguson M. et al. Antigenic and molecular properties of type 3 poliovirus responsible for an outbreak of poliomvelitis in a vaccinated population. J Gen Virol 1986: $67: 899-905$.

6. Hughes PJ. Evans IMA. Minor PD. Schild. GC. Almond JW. Stanway G. The nucleotide sequence of a type 3 poliovirus isolated during a recent outbreak of poliomyelitis in Finland. J (ien Virol 1986: 67: 2093-102.

7. Kitamura $\mathrm{N}$. Semler BL. Rothberg PG. et al. Primary structure gene organization and polvpeptide expression of poliovirus RNA. Nature $1981 ; 291: 547-53$.

8. Racaniello VR, \& Baltimore D. Molecular cloning of poliovirus CDNA and determination of the complete nucleotide sequence of the viral genome. Proc Natl Acad Sci LSA 1981: 78 $4887-91$

9. Ntanway (: Hughes P.J. Mountford RC et al. Comparison of the complete nucleotide sequences of the genomes of the neurovirulent poliovirus P3/Leon/37 and its attenuated Sabin vaceine derivative P3/Leon 12a b. Proc Natl Acad Sci CSA 1984: 81: 1539-43.

10. Nanger F. Nicklen S. Coulson AR. DNA sequencing with chainterminating inhibitors. Proc Natl Acad Sci LSA 1977: 74:5463-7.

11. Biggin MI). ( iibson T.J. Hong ( $\mathrm{XF}$. Buffer gradient gels and ${ }^{35} \mathrm{~s}$ label as an aid to rapid DNA sequence determination. Proc Natl Acad Sci LSA 1983; 80:3963-5.

12. Toyoda H. Kohara .I. Kataoka Y et al. Complete nucleotide sequences of all three poliovirus genomes. .J Molec Biol 1984; 174 : 561-85.

13. Conner B.J. Reyes AA. Morin C. Itakura C. Teplitz RL, Wallace RB. Detection of sickle cell $\mathrm{B}_{\text {- }}$-globin allele by hybridization with synthetic oliogonucleotides. Proc Natl Acad Sci LSA $1983: 80: 278-82$

14. Wallace RB. Shaffer J. Murphy RF. Bonner J, Hirose T. Itakura K. Hybridization of synthetic oligodeoxyribonucleotides to $\phi_{x} 174 \mathrm{DNA}$ : the effect of single base pair mismatch. Nucleic Acids Res 1979; $6: 3543-57$.

15. Cann A.J. Stanway G. Hughes PJ, et al. Reversion to neurovirulence of the live attenuated Sabin type 3 oral poliovirus vaccine. Nucleic Acids Res 1984; 12: 7787-92.

16. La Monica $\mathrm{N}$. Meriam C. Racaniello VR. Mapping of sequences required for mouse neurovirulence of poliovirus type 2 Lansing. J Virol 1986; 57: 515-25.

17. Minor PD. Dunn $G$. The effect of sequences in the $\overline{5}^{\prime}$ non-coding region on the replication of polioviruses in the human gut. J Gen Virol 1988; 69: 1091-6.

18. Kuge S. Nomoto A. Construction of viable deletion and insertion mutants of the Sabin strain of type 1 poliovirus: Function of the $5^{\prime}$ noncoding sequence in viral replication. $J$ Virol $1987 ; 61: 1478-87$.

19. Iizuka X. Kuge S. Nomoto A. Complete nucleotide sequence of the genome of coxsackievirus B1. Virology $1987: 156: 64-73$.

20. Lindberg AM. Stålhandske POK. Pettersson C. Genome of coxsackievirus B3. Virology $1987: 156: 50 \quad 63$

21. Jenkins O. Booth JD. Minor PD, Almond JW. The complete nucleotide sequence of roxsachievirus $\mathrm{B} 4$ and its comparison to other members of the picornaviridae. J Gen Virol $1987 ; 68: 1835-48$.

22. Evans DMA, Dunn G, Minor PD, et al. Increased neurovirulence associated with a single nucleotide change in a noncoding region of the Sabin type 3 poliovaccine genome. Nature 1985 : $314: 548-50$.

23. Salser W. Globin mRNA sequences: Analysis of base pairing and evolutionary implications. Cold Spring Harb Symp Quant Biol 1977; 42: 985-1002.

24. Rivera V.M, Welsh JD, Maizel JV Jr. Comparative sequence analysis of the $5^{\prime}$ noncoding region of the enteroviruses and rhinoviruses. Virology $1988 ; 165: 42-50$. 